\title{
Analysis of Career Management and Career Development as a Mediation of the Influence Leadership Role on Work Motivation in Bank Rakyat Indonesia
}

\author{
I Gusti Gede Narung ${ }^{1}$, Achmad Firdiansjah ${ }^{2}$, Harianto Respati ${ }^{3 *}$ \\ ${ }^{1}$ Master degree program in management, University of Merdeka Malang, Indonesia \\ ${ }^{2}$ Faculty of Economics and Business, University of Merdeka Malang, Indonesia \\ ${ }^{3}$ Faculty of Economics and Business, University of Merdeka Malang, Indonesia
}

\begin{abstract}
Article History
Received: 24.08 .2020

Accepted: 09.09.2020

Published: 03.10.2020

Journal homepage:

https://www.easpublisher.com/easjebm

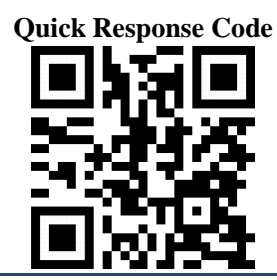
are credited.

\section{INTRODUCTION}

Bank is a business entity that collects funds from the community in the form of savings and distributes it to the community to improve the lives of many people. Banking was issued in the context of realizing a just and prosperous Indonesian society based on Pancasila and the Basic Law 1945. (Law-RI No. 7 of 1992 concerning Banking). Banks are a business of trust. Then it must provide good service which is a manifestation of the quality of human resources in the bank.
\end{abstract}

Abstract: This research explores four factors, namely leadership positions, career management, career development, and work motivation for employees. The objectives of this study are to analyze and explain the impact of leadership's position on work motivation by examining career management and career development as they interfere. The respondents of this study are permanent employees of the marketing department of PT. Bank Rakyat Indonesia (Persero) Tbk. Malang Martadinata Branch Office. A total of 41 people were sampled in this study. The analysis techniques are descriptive and multiple linear regression for confirmation on a structural equation model created by the researcher. A quantitative approach was chosen to explain the influence between research variables. Data collection using questionnaires. The results of this study found that the role of leadership showed insignificant symptoms on work motivation, but had a positive impact if mediated by career management and career development.

Keywords: Leadership, Career Management, Career Development, Work Motivation.

Copyright @ 2020: This is an open-access article distributed under the terms of the Creative Commons Attribution license which permits unrestricted use, distribution, and reproduction in any medium for non-commercial use (Non-Commercial or CC-BY-NC) provided the original author and source

In terms of ownership, there are state-owned banks, private banks, and foreign-owned banks. State Bank (government) is a bank whose shares are majority-owned by the government or state. A private bank is a bank whose shares are owned by a private party and a foreign bank is a bank whose shares are owned by a foreign party. PT. Bank Rakyat Indonesia (Persero) Tbk. Is one of the state banks or governmental bank that focuses on micro-businesses targeting small and medium enterprises (UMKM), therefore PT. Bank Rakyat Indonesia (Persero) Tbk. expanded credit to that sector which larger than other state-owned banks?
Motivation is a concept that the company usually uses to take care of its workers who have selfqualifications, expertise, and experience according to the company's needs, Kaseger [1].

Nowadays, the development of banking faces many obstacles and competition. Not only in the microlevel company but also greater level, national and internationally. It is caused by the market climate which is changing quickly and continuously. To deal with these conditions, companies have to make greater efforts by increasing the company's competitiveness. Rising the competitiveness of the company is inseparable from the efficiency of the company's existing human resources. The company must empower their workers to remain motivated. In general, internal and external factors affect the motivation of the employees. Internal factors are factors that come from the worker's side such as promotion, work performance, and work it. External factors such as respect, obligation, and acknowledgment are factors that help the employee work [2].

In previous empirical studies on the influence of the role of leadership on motivation, the results 
showed mismatch results. The results of Eva Varida Natalina MS [2] and Amirah 2012 research explained that there was a strong and significant relationship between the roles of leadership in motivating performance.

Besides, if successfully mediated by career management and career development, the relationship between the leadership and job motivation will have a great impact, there is a discrepancy where in previous studies the influence of career development has a direct influence on work motivation, this is according to the results of the last study Nur Noza Zakiah [4], Afriadie et al. [5], Jumiati Sasmita [6].

Explanation of the research gap on the influence of leadership roles on work motivation, lead to career management and career development as the solutions for solving theoretical problems. Therefore, a structural equation model needs to be formed in this study. This study places career management and career development as moderating variables. Employee work motivation is the goal to be achieved by the leadership role to improve employee performance.

Based on the phenomenon explained that the target of achieving work motivation for several indicators. The implementation of human resource management at PT. Bank Rakyat Indonesia (Persro) Tbk: Malang Martadinata Branch Office in the successful category. This study needs to examine the effect of career management truth and career development on work motivation by considering other factors, the role of leadership in BRI.

\section{THEORETICAL FrAMEWORK}

\author{
Motivation \\ Motivation will be important because it is \\ expected that every employee will work hard and be \\ enthusiastic to achieve high performance. According to \\ Gibson [7], Motivation is the force that drives an \\ employee who gives rise to and directs behavior. \\ Motivation is a psychological process arousing and \\ directing behavior towards the achievement of goals or \\ gold directed [8].
}

\section{Career Development}

Based on Dessler [9] career development is a set of lifetime activities that contribute to exploitation, stabilization, success, and achievement in career. Career development (promotion) is expected by employees, since workers would get better rights with this development than before, both material and nonmaterial. Well-designed career development will help in determining the needs of employees with company goals.

\section{Career management}

Simaora [10] claimed that careers can be observed from an objective and subjective viewpoint, from an objective career perspective a shift in beliefs, attitudes, and motives happening as someone is getting older, and from a subjective perspective career is the stage of someone's position during his lifetime. Career management as a career cycle for workers that involves career preparation, growth, career counseling, and career decision making.

\section{Role of Leadership}

A role of leadership is a set of behaviors and efforts made by leaders related to improving the performance of marketers [11]. Leadership's position in moving subordinates is vital; the leader has the authority and a very strategic task. Leaders who focus on skills and abilities will enhance procedural awareness of employees to support and inspire workers to learn new ways of doing jobs [12].

\section{The Research Framework is}

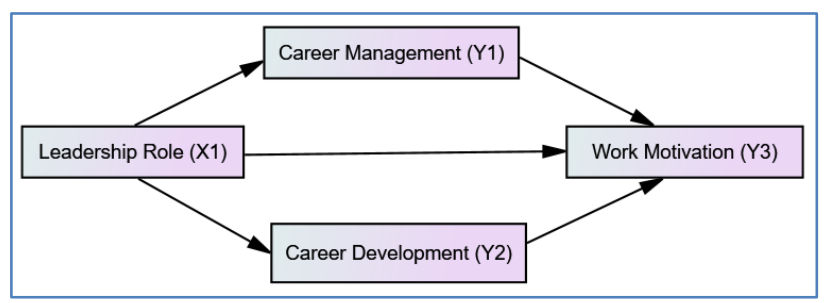

Fig-1: The Structural Equation Modeling

\section{Methodology}

\section{Research Design}

The approach used in this study is the explanation method, in this study using three variables. Descriptive analysis is used to explain the picture of each variable studied and multiple linear regression analysis is used to determine the effect between the variables tested. The questionnaire was used to collect primary data. Respondents only chose answers according to the Likert scale on choice 1 is strongly disagree, 2 disagrees, 3 is neutral, 4 agrees and choice 5 strongly agrees.

\section{Sample and Population}

Respondents in this study were 142 permanent employees of the marketing division of PT. Bank Rakyat Indonesia (Persero) Tbk: Malang Martadinata Branch Office. This research was conducted from January $3^{\text {rd }}, 2020$ to January $13^{\text {th, }}$ 2020. The Slovin formula is used to determine the sample by considering the error rate of $5 \%$, to obtain a total sample size of 42 of the 142 population of marketing personnel. Sampling uses simple random sampling that every employee has the same opportunity to answer the research questionnaire. 


\section{Variable and Indicators}

The role of leadership is measured by three indicators, namely the interpersonal role, the informational role, and the decision making role. Career management is defined by four indicators, namely career plans, career opportunities, career support, and career support data. Career development is measured by two indicators, namely career planning and career management. Work motivation is measured by two indicators, namely the motivation factor and the maintenance factor. The structure of the variables, indicators, and the number of research instruments is described in Table 1.

Table-1: Variable, indicator dan research instrument

\begin{tabular}{|l|c|}
\hline \multicolumn{1}{|c|}{ Variables and Indicators } & Number of instruments \\
\hline Leadership Role (X1) & 2 \\
\hline Interpersonal role (X1.1) & 2 \\
\hline Informational role (X1.2) & 2 \\
\hline Decision Making Role (X1.3) & \\
\hline Career Management (Y1) & 2 \\
\hline Career Plan (Y1.1) & 2 \\
\hline Career Chance (Y1.2) & 2 \\
\hline Career Support (Y1.3) & 2 \\
\hline Career Support Data (Y1.4) & \\
\hline Career Development (Y2) & 3 \\
\hline Career Planning (Y2.1) & 3 \\
\hline Career Management (Y2.2) & \\
\hline Work Motivation (Y3) & 3 \\
\hline Motivation Factor (Y3.1) & 2 \\
\hline Maintenance factor (Y3.2) & 25 \\
\hline Total & \\
\hline
\end{tabular}

\section{RESEARCH Finding}

\section{Respondent's Profiles}

According to the profile of respondents, most have Strata 1 (S1) education level which equal to
$78.17 \%$, it means that respondents at the educational level of Strata1 (S1) have the potential on career development within a work period between 3 to 5 years the respondent already has the ability and professional at work.

Table-2: Profil Respondent

\begin{tabular}{|l|r|l|r|l|c|}
\hline \multicolumn{1}{|c|}{ Age } & \multicolumn{1}{c|}{$\%$} & Education Level & \multicolumn{1}{c|}{ Work Period } & $\mathbf{\%}$ \\
\hline 20-25 years & 6,34 & High school & 1,41 & $1-3$ years & 15,49 \\
\hline 26-30 years & 23,24 & Diploma & 19,01 & $>$ 3-5 years & 71,13 \\
\hline 30-35 years & 56,33 & Bachelor & 78,17 & $>$ 5-10 years & 10.56 \\
\hline 36-40 years & 11,27 & Magister & 1,41 & $>10$ years & 2.82 \\
\hline$>$ 40 years & 2,82 & & & & \\
\hline
\end{tabular}

\section{DeSCRIPTIVE AnAlysis RESUltS}

Data Analysis is processed by using the SPSS program (Statistical Package for Social Science), there are four variables, ii indicators with a total of 25 items. The results of validity and reliability testing of 25 items/items proved to be valid from the probability of each instrument not exceeding than 5\% of the error rate, it means that the respondent knew the purpose of the measurements contained in the questionnaire. The results of the reliability test of the research instrument showed a good level of reliability as proven by the value of Cronbach Alpha not exceeding the r-table value $(0.308)$. The results of the descriptions for each indicator of the research variable and 25 instruments are presented. An explanation of the respondents' perceptions can be analyzed from the average value generated by the indicators and instrument items. The indicator that best describes the leadership role variable is the informational role, namely on the point of the leader supervising the work of subordinates. The indicator that best describes the career management variable is the company giving rewards to employees who have good performance. For career development variables, indicators that best describes career development is the existence of career opportunities in the company, while for the variable work motivation the indicator that best describes work motivation is an increase in work performance and employees feel valued by the company. 


\section{Linear Regression Analysis Results}

To create a structural equation model, regression is needed. The results of structural equation regression are:

First Structural Equation model: $\mathrm{Y} 1=$ 0,492x1+0,324+e1 Second Structural Equation Model: Y2 = $0,566 \times 1+0,426+\mathrm{e} 2$

$$
\text { Note: } \begin{aligned}
\text { X1 } & =\text { Role of Leadership } \\
\text { Y1 } & =\text { Career Management } \\
\text { Y2 } & =\text { Career Development } \\
\text { Y3 } & =\text { Work Motivation }
\end{aligned}
$$

Result of structural equation modeling as described in Figure 2.

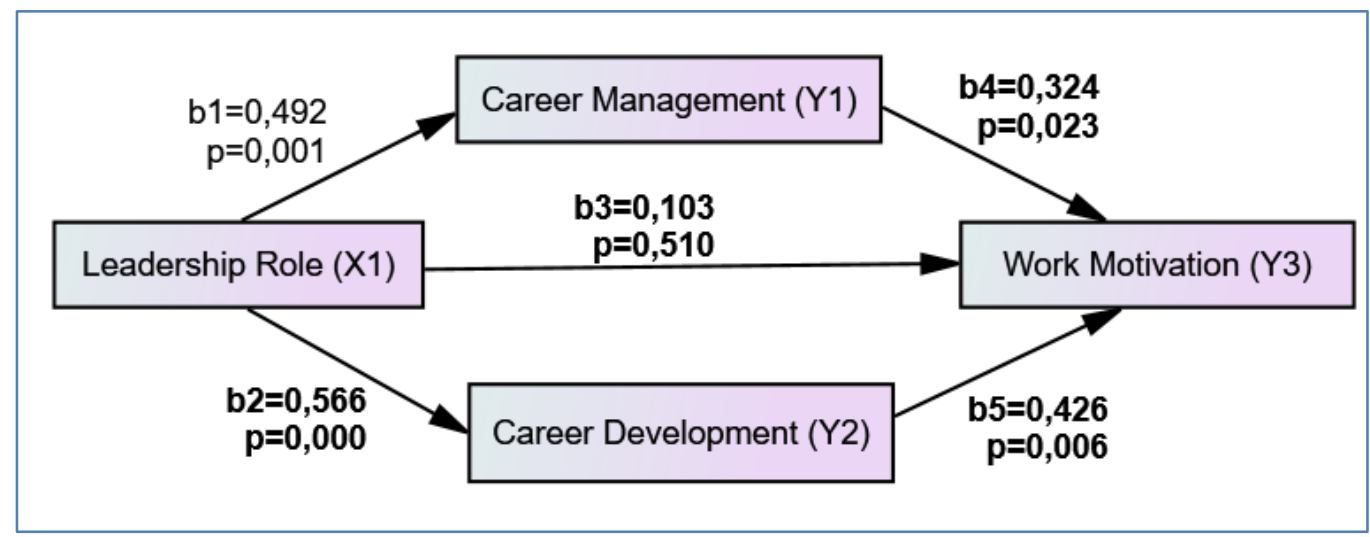

Fig-2: Result of Path Analysis's Evaluation

Figure 2. There are five coefficiencies of regression on the structural equation model. Cooficiencies od regression in the role of leadership towards motivation showed an insignificant relationship, while another 4 proficiencies of regression

\begin{tabular}{|c|c|c|c|c|c|}
\hline \multirow{2}{*}{\multicolumn{3}{|c|}{ Variable }} & \multirow{3}{*}{$\begin{array}{l}\text { Direct } \\
\text { Effect }\end{array}$} & \multirow{3}{*}{$\begin{array}{c}\text { Indirect } \\
\text { Effect }\end{array}$} & \multirow{3}{*}{$\begin{array}{c}\text { Total } \\
\text { Effect }\end{array}$} \\
\hline & & & & & \\
\hline Exogen & Mediation & Endogen & & & \\
\hline $\begin{array}{l}\text { Leadership } \\
\text { Role }\end{array}$ & $\begin{array}{l}\text { Career } \\
\text { Management }\end{array}$ & - & $0,492 *$ & - & $0,4922^{*}$ \\
\hline $\begin{array}{l}\text { Leadership } \\
\text { Role }\end{array}$ & $\begin{array}{l}\text { Career } \\
\text { Development }\end{array}$ & - & $0,566^{*}$ & - & $0,566^{*}$ \\
\hline $\begin{array}{l}\text { Leadership } \\
\text { Role }\end{array}$ & - & $\begin{array}{l}\text { Work } \\
\text { Motivation }\end{array}$ & 0,103 & - & 0,103 \\
\hline- & $\begin{array}{l}\text { Career } \\
\text { Management }\end{array}$ & $\begin{array}{l}\text { Work } \\
\text { Motivation }\end{array}$ & $0,324 *$ & - & $0,324 *$ \\
\hline- & $\begin{array}{l}\text { Career } \\
\text { Development }\end{array}$ & $\begin{array}{l}\text { Work } \\
\text { Motivation }\end{array}$ & $0,426^{*}$ & - & $0,426^{*}$ \\
\hline $\begin{array}{l}\text { Leadership } \\
\text { Role }\end{array}$ & $\begin{array}{l}\text { Career } \\
\text { Management }\end{array}$ & $\begin{array}{l}\text { Work } \\
\text { Motivation }\end{array}$ & 0,103 & $\begin{array}{c}0,492 * \mathrm{x} 0,324 * \\
0,159\end{array}$ & $0,1592^{*}$ \\
\hline $\begin{array}{l}\text { Leadership } \\
\text { Role }\end{array}$ & $\begin{array}{l}\text { Career } \\
\text { Development }\end{array}$ & $\begin{array}{l}\text { Work } \\
\text { Motivation }\end{array}$ & 0,103 & $\begin{array}{c}0,566^{*} \mathrm{x} 0,426^{*} \\
0,241^{*}\end{array}$ & $0,2414^{*}$ \\
\hline
\end{tabular}
showed significant effects. The results of the path analysis showed in Table 3 .

Table-3: Results of Path Analysis

$$
\text { Level of significan }(p)=5 \%
$$

Note: Path X1 toward Y3, showed insignificantly affected so that the coefficient value 0,103 considered as Null $(\beta 3=0$ or Ho accepted)

\section{DISCUSSION}

Leadership Role, Career Management, and Career Development and Work Motivation first hypothesis showed that the role of leadership does not affect work motivation if it is not mediated by career management and career development. This contradicts the results of previous research conducted by Eva Varida Natalina MS [3] with the title of the influence of leadership roles and job promotion on work motivation which has an impact on improving employee performance at Perum Peruri Karawang. It is concluded that leadership roles have a significant effect on work motivation. 
The role of leadership on work motivation through career management partially and simultaneously there is a significant influence, this is supported by previous research conducted by Asnar [13] with the title influence of the relationship between career management and employee work motivation of PT. Bank Negara Indonesia (Persero) Tbk; The Main Branch Office of the University of Indonesia, Depok, shows that career management has a significant effect on motivation. The application of career management in the company will impact on the work performance of employees; this is because the company provides rewards (rewards) to employees who excel so that it will motivate employees to work well.

The results of the analysis showed that the role of leadership has a significant effect on work motivation through career development, this is supported by the results of previous research conducted by Nur Noza Zakiah [14] with the title the influence of leadership roles and career development on the work motivation of PT. Bank BJB Tbk: Bandung Main Branch, shows there is a significant influence between career development and work motivation. Determination of career development will have an impact on employee motivation; this is because employees feel there are career opportunities in the company so that employees will continue to work optimally to achieve the desired career.

\section{CONCLUSION}

The results of this research proved the roles of Leadership in PT. Bank Rakyat Indonesia (Persero) Tbk: Malang Martadinata Branch Office studied the influence of motivation mediated by career management and career development. Then, the roles of leadership do not have a direct impact on motivation. Career management can indirectly affect the role of leadership in work motivation.

However, career development is the most dominant in mediating the role of leadership on work motivation. For this reason, further researchers are advised to conduct a deeper study of career development, namely by providing opportunities to develop the widest possible employee career to improve the quality of human resources to prepare human resources for the future.

\section{REFERENCES}

1. Kaseger, R. G. (2013). Pengembangan Karir Dan Self-Efficacy Terhadap Kinerja Karyawan Pada PT Matahari Department Store Manado Town Square. Emba, 1 (4), 906-916.
2. Santoso, E. (2013). The Influence of Leadership, Motivation, Compensation, and Work Discipline on Employee Performance at Bank Central Asia Kudus. E-journal. Universitas Diponegoro

3. Natalina, E. V. (2018). Pengaruh peran kepemimpinan dan promosi jabatan terhadap motivasi kerja yang berdampak pada peningkatan kinerja karyawan perum peruri karawang. Jurnal Manajemen \& Bisnis Kreatif, 3(2).

4. Haryani, P. Y. (2014). Correlation between career development and work motivation and desire for early retirement. Buletin Studi Ekonomi.

5. Alif, A. (2015). The Influence of Work Motivation, Career Development, and Work Environment on Organizational Citizenship Behavior (OCB) with Job Satisfaction as an Intervening Variable in Lpg Terminal Companies. MIX. Jurnal Ilmiah Manajemen, 5(2).

6. Sasmita, J. (2012). Pengaruh Pengembangan Karir Terhadap Motivasi Dan Kinerja Pegawai Negeri Sipil Di Provinsi Riau.

7. Paputungan, F. R. (2013). Motivation, Career Paths and Work Discipline Influence on Employee Performance at PT. Bank Sulut, Calaca Branch. Jurnal EMBA: Jurnal Riset Ekonomi, Manajemen, Bisnis dan Akuntansi, 1(4).

8. Wibowo, F. W. (2010). Mergesort dalam Tingkat Register Transfer Logic Berbasis Field Programmable Gate Array. Data Manajemen dan Teknologi Informasi (DASI), 11(4), 33.

9. Yang, P., Hong, G., Dessler, A. E., Ou, S. S., Liou, K. N., \& Minnis, P. (2010). Contrails and induced cirrus: Optics and radiation. Bulletin of the American Meteorological Society, 91(4), 473-478.

10. Simamora, B. (2001). Memenangkan pasar dengan pemasaran efektif dan profitabel. Jakarta. Gramedia Pustaka Utama.

11. Thoha, H., \& Amri, K. (2011). Composition and abundance of phytoplankton in south Kalimantan waters. Oseanologi dan Limnologi di Indonesia, 37(2), 371-382.

12. Jaworski, B. J., \& Kohli, A. K. (1996). Market orientation: review, refinement, and roadmap. Journal of Market-Focused Management, 1(2), 119-135.

13. Wijaya, S. M., Farida, N., \& Asnar, E. (2012). Sweet star fruit reduces blood pressure in normotensive subjects. Folia Medica Indonesiana, 48(4), 198.

14. Jantitya, S. V., \& Sari, D. P. (2014). Analysis of the Effect of Work Discipline, Motivation, and Career Development on Employee Performance (Case study in PT. Bank Mandiri (Persero), Tbk Cabang Daan Mogot Jakarta. Industrial Engineering Online Journal, 3(3). 


\section{APPENDIX}

\begin{tabular}{|c|c|c|}
\hline Variables & Indicators & Items of statement \\
\hline \multirow{10}{*}{$\begin{array}{l}\text { Roles of } \\
\text { Leadership } \\
\text { (X1) }\end{array}$} & \multirow{3}{*}{ Interpersonal Roles (X1.1) } & X1.1.1 Organization's Symbol \\
\hline & & X1.1.2 Motivating and Developing \\
\hline & & X1.1.3 As Connector / Mediator \\
\hline & \multirow[t]{3}{*}{ Informational Roles (X1.2) } & X1.2.1 As Supervisor \\
\hline & & X1.2.2 As Spreader \\
\hline & & X1.2.3 As Spokesperson \\
\hline & \multirow{4}{*}{$\begin{array}{l}\text { Decision Making Roles } \\
\text { (X1.3) }\end{array}$} & X1.3.1 As an entrepreneur. \\
\hline & & X1.3.2 Resources Allocator \\
\hline & & X1.3.3 Organization Controller \\
\hline & & X1.3.4 Negotiator \\
\hline \multirow[t]{11}{*}{$\begin{array}{l}\text { Career } \\
\text { Management }\end{array}$} & \multirow{4}{*}{ Career Planning (Y1.1) } & $\begin{array}{l}\text { Y1.1.1 Company has a specific career } \\
\text { planning on the recruitment process. }\end{array}$ \\
\hline & & Y1.1.2 Company has recruitment planning. \\
\hline & & Y1.1.3 Evaluation Planning \\
\hline & & Y1.1.4 Reward Planning \\
\hline & \multirow[t]{2}{*}{ Career Opportunity (Y1.2) } & Y1.2.1 Career Opportunity for Employee \\
\hline & & $\begin{array}{l}\text { Y1.2.2 Opportunity to choose a career of } \\
\text { interest. }\end{array}$ \\
\hline & \multirow{3}{*}{ Career Engagement (Y1.3) } & $\begin{array}{l}\text { Y1.3.1 Encouraging employees to pursue } \\
\text { careers }\end{array}$ \\
\hline & & $\begin{array}{l}\text { Y1.3.2 Paying attention to outstanding } \\
\text { employees to move forward. }\end{array}$ \\
\hline & & $\begin{array}{l}\begin{array}{l}\text { Y1.3.3 Encouraging employees to pursue } \\
\text { careers. }\end{array} \\
\end{array}$ \\
\hline & \multirow[t]{2}{*}{$\begin{array}{l}\text { Data for Career Engagement } \\
\text { (Y1.4) }\end{array}$} & $\begin{array}{l}\text { Y1.4.1 Accurate data system for on-going } \\
\text { employees. }\end{array}$ \\
\hline & & $\begin{array}{l}\text { Y1.4.2 Accurate data system for future } \\
\text { employees. }\end{array}$ \\
\hline \multirow{7}{*}{$\begin{array}{c}\text { Career } \\
\text { Development } \\
\text { (Y2) }\end{array}$} & \multirow{3}{*}{ Career planning (Y2.1) } & $\begin{array}{l}\text { Y2.1.1 Matching interests and expertise in } \\
\text { work }\end{array}$ \\
\hline & & $\begin{array}{l}\text { Y2.1.2 Career development inside the } \\
\text { organization }\end{array}$ \\
\hline & & Y2.1.3 Short and Long term career clarity. \\
\hline & \multirow{4}{*}{ Manajemen Karir (Y2.2) } & Y2.2.1 Integrated Human Resources Planning \\
\hline & & Y2.2.2 Career Information \\
\hline & & Y2.2.3 Work experiences \\
\hline & & Y2.2.4 Training Education \\
\hline \multirow{8}{*}{$\begin{array}{l}\text { Work Motivation } \\
\text { (Y3) }\end{array}$} & \multirow[t]{3}{*}{ Motivation factors (Y3.1) } & Y3.1.1Achievement \\
\hline & & Y3.1.2 Recognition \\
\hline & & Y3.1.3 Work itself \\
\hline & \multirow{5}{*}{ Maintenance factors (Y3.2) } & Y3.2.1 Work Condition \\
\hline & & Y3.2.2 Salary Payment \\
\hline & & Y3.2.3 Organization Policies \\
\hline & & Y3.2.3 Interpersonal Relationship \\
\hline & & Y3.2.4 Quality Control \\
\hline
\end{tabular}

